\title{
MANAGING LAWNS IN SHADE
}

\author{
Ali Harivandi \\ University of California Environmental Horticulture Advisor \\ Alameda, Contra Costa, and Santa Clara Counties \\ Victor A. Gibeault \\ Environmental Horticulturist \\ University of California Cooperative Extension, Riverside County
}

$\mathrm{M}$ aintaining a lawn in the shade cast by trees, shrubs, and structures is challenging for homeowners and turf professionals alike. Most turfgrasses require 4 to 5 hours of full sun per day or an entire day of filtered light. If the amount of light is reduced, photosynthesis (a plant's incorporation of atmospheric carbon dioxide into carbohydrates) and carbohydrate production are reduced. When carbohydrate production drops below a certain level, the development of roots, stolons, and rhizomes is curtailed and the turfgrass deteriorates. Trees with dense canopies, such as oak, maple, carob, magnolia, olive, and conifers, are most likely to create problems of reduced light for turfgrasses; their shallow feeder roots also compete with the grass for water and nutrients. Turfgrasses grown in the shade are also stressed by restricted air movement, which keeps turf wet for long periods - especially after irrigation, rain, or dew fall-creating an environment that encourages disease.

\section{SYMPTOMS}

Symptoms of deteriorating turfgrass include development of fine leaves, reduced shoot and root growth, reduced shoot density, reduced tillering (growth of secondary stems), delayed leaf initiation, longer leaves, more upright growth habit, and succulent growth. Each of these symptoms make turf more susceptible to disease and less tolerant to traffic, heat, cold, and drought.

\section{REMEDIES}

Growing a lawn in the shade is not impossible with proper management. The following practices will help ensure success.

\section{Turfgrass Selection}

Selecting a turfgrass species or cultivar that is adapted to shade is the single most important factor in growing turf successfully in the shade. The relative shade tolerances of turfgrasses commonly grown in California appear in the table at the end of this publication.

\section{Shade Modification}

A shady environment can often be modified to improve conditions for turfgrass. To increase the amount of light reaching the turf, selectively prune tree branches. Pruning is particularly effective for dense shade trees such as maple and oak. Remove limbs within 8 feet $(2.4$ $\mathrm{m}$ ) of the ground to allow direct sunlight to reach the turf during early morning and late afternoon. Dense underbrush, hedges, or shrubs in the shaded area should be thinned or removed to allow air to move over the turf surface.

We do not recommend pruning of shallow tree roots. Most of a tree's feeder roots grow in the upper 18 inches $(45 \mathrm{~cm})$ of soil, and removing them significantly reduces the tree's water and nutrient uptake. Although the negative effects of this reduction may not appear for 3 to 4 years, it may then be too late to save the tree. Practices not as damaging as tree root pruning include deep irrigation and fertilization of trees to discourage shallow feeder roots. If exposed tree roots make mowing difficult, a uniform shallow topsoil or sand dressing around the tree may solve both problems. Never cover exposed tree roots with a layer of soil deeper than 1 to $11 / 2$ inches $(2.5-3.7 \mathrm{~cm})$.

\section{Cultural Practices}

Mowing. Raising the mowing height of a shaded turf surface $1 / 4$ to $1 / 2$ inch $(6-12 \mathrm{~mm})$ above normal increases leaf area and allows for more efficient absorption of light. Increased mowing height also encourages deeper and more extensive rooting, which enhances the turf's ability to compete with trees for water and nutrients, and alleviates the thin appearance caused by reduced shoot density. In addition, the higher cut ordinarily reduces mowing frequency, which means fewer open

University of California - Division of Agriculture and Natural Resources Publication 7214 
wounds on the leaves (and less likelihood of disease) and less traffic on the lawn. Because turfgrass in shade is less tolerant to wear, all traffic on shaded turf should be kept to a minimum.

Irrigation. Proper irrigation is crucial to managing lawns in shade, where turf root systems are severely weakened and tree roots take up moisture more readily. We recommend heavy, infrequent irrigation to encourage trees to grow deeper roots, reducing the competition for moisture in the turfgrass root zone. Deep, infrequent watering also reduces disease by decreasing the amount of time the lawn is wet. Turf should be watered early in the morning to allow the surface to dry rapidly. Late-evening or night watering leaves the lawn wet too long, promoting disease.

Fertilization. Proper nitrogen $(\mathrm{N})$ fertilization is also very important for the shady lawn. Too much $\mathrm{N}$ can be detrimental because it encourages turfgrass shoot growth over root growth. It also encourages formation of succulent tissue, which is highly susceptible to infection and traffic injury.

The $\mathrm{N}$ requirement of turfgrasses grown in shade is approximately half that of turf grown in full sun. Only minimum amounts of $\mathrm{N}$ should be applied to cool-season turfgrasses during the summer. Fall and spring are the best times to apply fertilizer to shaded turf. Maximize potassium (K) fertilization on turfgrass grown in shade. Potassium increases shade tolerance of turfgrasses. Do not apply surface fertilizer to trees in the area. Place the fertilizer about 10 inches $(25 \mathrm{~cm})$ below the soil surface, in the zone of greatest tree root activity and below most of the turfgrass root system.

Other cultural practices. Reduce traffic on lawns growing in shade. Promptly remove fallen tree leaves. Leave a turf-free zone of 2 to 3 feet $(60-90 \mathrm{~cm})$ around small trees to improve growth and reduce mower injuries.

If it is not possible to renovate a poorly performing, shade-intolerant turfgrass stand, overseeding with a shade-tolerant grass species is a possible compromise. For example, an established stand of bermudagrass growing poorly in deep shade could be overseeded with hard or red fescue, or, in medium shade, tall fescue. Before overseeding, mow the grass short and cultivate the soil slightly with a rake or power renovator to prepare the seed bed. Then spread the seed, fertilize, and topdress with a light covering of native or on-site soil. Irrigate to germinate the seeds and help the grass become established.

\section{Disease Control}

Effective disease control is essential on shady lawns. In general, disease is not a serious problem for most warm-season turfgrasses, if they can be grown in the shade. Cool-season grasses, however, are often infected and damaged. Follow all suggested cultural practices to minimize the possibility of turfgrass disease.

\section{ALTERNATIVES TO TURFGRASS}

Very dense shade may make it impossible to establish or maintain a satisfactory lawn, even with proper turfgrass selection and management. In these cases it is best to use a shade-adapted ground cover. Examples of commonly used shade-adapted ground covers are English ivy, myrtle, Ajuga, baby tears, Potentilla, and lily turf. If plant materials are not suitable or cannot be worked into the landscape satisfactorily, decorative mulches such as shredded bark chips, wood chips, or gravel may provide useful alternatives.

\section{Shade Tolerance of Common California Turfgrasses}

\begin{tabular}{|c|c|c|c|c|}
\hline Turfgrass type & Excellent & Good & Medium & Poor \\
\hline Cool-season & $\begin{array}{l}\text { hard fescue* } \\
\text { red fescue* } \\
\text { Chewings fescue* } \\
\text { rough bluegrasst }\end{array}$ & tall fescue & $\begin{array}{l}\text { creeping bentgrass } \\
\text { colonial bentgrass } \\
\text { Kentucky bluegrassł }\end{array}$ & $\begin{array}{l}\text { Kentucky bluegrass } \\
\text { perennial ryegrass } \\
\text { annual ryegrass }\end{array}$ \\
\hline Warm-season & St. Augustinegrass & $\begin{array}{l}\text { zoysiagrass } \\
\text { seashore paspalum }\end{array}$ & - & $\begin{array}{l}\text { bermudagrass } \\
\text { kikuyugrass } \\
\text { buffalograss }\end{array}$ \\
\hline
\end{tabular}

* Dry shade. †Wet shade. $¥$ Some Kentucky bluegrass cultivars perform poorly in shade.

The University of California, in accordance with applicable Federal and State law and University policy, does not discriminate on the basis of race, color, national origin, religion, sex, disability, age, medical condition (cancer-related), ancestry, marital status, citizenship, sexual orientation, or status as a Vietnam-era veteran or special disabled veteran. The University also prohibits sexual harassment. This publication is available in alternative media on request. Inquiries regarding the University's nondiscrimination policies may be directed to the Affirmative Action Director, University of California, Agriculture and Natural Resources, 300 Lakeside Drive, 6th Floor, Oakland, CA 94612-3560; (510) 987-0096.

74-pr-8/96-SB

ISBN 978-1-60107-006-7 